\title{
CORPORATE GOVERNANCE MODEL OF A STATE-OWNED ENTERPRISE: EVIDENCE FROM AN ASIAN EMERGING MARKET
}

\author{
Hisham Yaacob ${ }^{1}$ \\ Department of Accounting \& Finance \\ Faculty of Business, Economics \& Policy Study \\ University of Brunei Darussalam \\ Tungku Link, Gadong \\ Brunei BE1410 \\ Jefri Basiuni \\ Faculty of Business and Computing \\ Institute of Technology Brunei \\ Tungku Link, Gadong \\ Brunei BE1410
}

\begin{abstract}
Purpose of the study - Corporate governance has attracted much attention and is still a hot topic among shareholders, directors and company regulators. Failure of large corporations in the past decades not only affected the shareholders and investors, rather it adversely affects all the stakeholders. Good corporate governance practices are argued to curb company's failures due to fraudulent activities, collusion schemes and mismanagement. The purpose of this study is to examine a state-owned enterprise corporate governance model. There is still a gap in the corporate governance model literature especially in the context of an emerging Asian market. This study is embarked to fill the gap.

Design/Methodology/Approach - The study took the qualitative approach. It utilized case study method. As it is a single case study, only one sample is chosen using the convenience or purposive sampling technique. Informal and semi-structured interviews are conducted with two representatives from the company. Data is also sourced from published documents related to the company. The company is designated as Company $\mathrm{R}$ as the study is not allowed to reveal the company's real name.

Findings - The study found that the corporate governance structure of the board is of unitary or one tier board. This is common in the Anglo American settings. The Board of Directors (BoD) is accountable to the shareholder. They are entrusted with the responsibilities to manage the business. The board member are selected and appointed by the government. Most of them are senior government officials with some representation from the industry. They are chosen from highly capable and trustworthy government officers to represent and safeguard the government's interest in the company. The shareholding of the company is $100 \%$ owned by the government. Therefore, any issues with minority shareholders do not exist. Representatives of the government sit on the board. They are all nonexecutive directors. The company did not practice Chief Executive Officer (CEO) duality roles (CEO and Chairman of the board). As for the structure of ownership, it is a typical company with the other Asian state-owned enterprises where the state has full ownership and control of the company. Hence, the company board is under the state direct control. They are also required to submit the annual report and audited financial statements every year. Apart from that, the board is also required to send company's performance and financial standing on a regular basis to the government.

Limitation /scope of the study - The study faced several limitations in terms of getting information from the company as most information especially financials are regarded as confidential. Nevertheless, the study manages to get the necessary information for the purpose of this research. The data collected are just enough to fulfil the research objectives and answer the research questions on examining the corporate governance model. The sample of the study
\end{abstract}

${ }^{1}$ Corresponding author: Hisham Yaacob, Department of Accounting \& Finance, Faculty of Business, Economics \& Policy Studies, University of Brunei Darussalam, Tungku Link, Gadong, BruneiDarussalamBE1410. Email: hisham.yaacob@ubd.edu.bn. Telephone: +6732463001. 
is only one organization hence the findings and results may not be generalized. The conclusion is also exclusive to the selected sample and may not be applicable to other state-owned companies in Asian emerging markets.

Originality/Value - The study fills the gap in the corporate governance model literature especially in the context of Asian emerging economies state-owned companies. Furthermore, we believe that this study is among the first to examine the corporate governance model in this country. It shed lights on the corporate governance model in terms of governance structure, the ownership and shareholders right, roles of the board, regulatory framework and control mechanism and lastly disclosure and transparency. It shows that the company having the same model as what is found in the Anglo American model without having a supervisory board as what is common in Continental European and Japan companies.

Conclusion - The company is having a unitary or one tier board structure that is common in the Anglo-American model. The board ultimately reports to the government as they are the sole shareholder of the company. As such, all the directors are non-executive directors. The board members are selected and appointed by the government comprises of senior government officials with minority representation from the industry. There is no problem with minority shareholders as there are none. However, the company is still regulated under the Companies Act. It is also mandated to produce annual report and audited financial statements to the government although the documents are classified as confidential. As governance control measure the company is also required to submit periodical company performance and financial position for the government perusal.

Keywords: Anglo-American, Asean, board of directors, corporate governance, corporate governance model, emerging market, European model, management board, state-owned enterprise, unitary board, supervisory board

\section{Introduction}

Corporate governance is still a hot topic amongshareholders, regulators and society at large and received increased attention in the past decades (Smolo and Smajic, 2011). Good corporate governance is demanded from the company directors and management as well as other important actors (stakeholders) such as the employees, government and the public. The newest global financial crises circa 2008 (sub-prime mortgage in the United States) and the collapsed of big corporation i.e. Lehman Bros., J.P. Morgan, Morgan Stanley and others, due to fraudulent activities and mismanagement (Enron, Arthur Anderson, WorldCom) has put corporate governance in the limelight more than ever before (Dalton and Dalton, 2010; Myers and Ziegenfuss, 2006; Yaacob, Jaya and Hamzah, 2012; Young and Thyil, 2008). Most are the results of ethical 'scandals' (Karns, 2011).

There has been an increase in the number of government reports, stock exchange regulations (Sarbanes-Oxley in the United States) and literature on contemporary board roles and how it can become more effective(Dalton and Dalton, 2010; Strikwerda, 2003;Myers and Ziegenfuss, 2006; Strebel, 2011). It is argued that the board and the directors faced three major challenges. First, they have to identify changes that can enhance the governance. Second they need to ensure that these changes will enhance the performance of their organization. Finally, the board need to identify the methods or techniques required to bring about the changes.

The study applies the definition of corporate governance by the Organization for Economic Cooperation and Development (OECD) which defined it as, "a set of relationship between a company's management, its board, shareholders and other stakeholders. Corporate governance also provides the structure through which the objective and monitoring performance are determined" (OECD, 2004). In essence, the concept of corporate governance refers to the coordination of the organization various stakeholder's interest. Among them are the shareholders, management, employees, creditors, customers, suppliers, the government, thepublic and the environment.

In every company, there is a relationship between the physical or legal persons who has a vested interest in the business. In pursuit of the entrepreneurial activities, the management or the governance of the company must take into account the inherent conflicts produced by the co-existence of multiple interests inside and outside the corporation. The study focused on the corporate governance model of a state-owned enterprise, Company $\mathrm{R}$ in order to shed light on the enterprise corporate governance model contemporary practises.

The paper is organized in the following manner: Section 2 discussed the literature review followed by section 3 on research methodology. Next, findings and discussion is presented in section 4. Finally, the summary and conclusion of the study is tabled in Section 5. 


\section{Literature Review}

There is a dearth of literature in corporate governance model of state-owned companies (Khongmalai, Tang and Siengthai, 2010). However, the interest to study corporate governance model in corporations are many. Some even suggested for new and holistic model (Young and Thyil, 2008); entrepreneurship model (Strikwerda, 2003); and intouch boards (Strebel, 2011). It is argued that state-owned companies are normally secretive and they tend to be very difficult to study (Yaacob et al., 2012). This study respected the need to keep most of the things confidential and highlight only general corporate information. The study narrows down the corporate governance model of Company $\mathrm{R}$ into five different aspects of governance areas, (1) Governance e structure; (2) Ownership and shareholders right; (3) Roles of the board; (4) Regulatory framework and control mechanism; and (5) Disclosure and transparency.

This section begins with the three distinct corporate governance model found in the literature. Next, a discussion on the roles and responsibilities of board of directors is presented followed by the rights and concentration of shareholders. Then regulatory framework and control mechanismand lastly disclosure and transparency.

\subsection{Models of corporate governance}

Ooghe and Langhe (2002) cautioned that it would be unfair to compare the benefits of different corporate governance model practiced by companies in isolation. It may lead to misinterpretation and the purpose is not to determine whether the particular model (effectiveness) is better than the other without taking into consideration of the business context (Lubatkin et al., 2005). This is even crucial if the business organization operates for instance, in the Asian countries where culture is influencing the way business is conducted (Witt, 2012).

As extensively explored by Tricker (2009), corporate governance models may be seen as being shaped based on the two distinct board systems. Unitary board which is common in the United States and the United Kingdom including the commonwealth countries; typically consist of shareholders at the top of the hierarchy. The day-to-day affairs of the corporation are in the hands of the board of directors as the governing body with predominance of independent outside directors. While the Chief Executive Officer (CEO) may hold dual responsibilities of Chief Executive Officer and as Chairman of the board. This is a common practice in the United States and many family-owned companies around the world.

The proponents of stewardship theory strongly agree to the dual roles as they claimed that it give the incumbent more power to steer the company and make decision without being much argued by the board (Davis, Schoorman and Donaldson, 1997). However, such dual roles are usually separated in the United Kingdom; the board in turn keep an eye over the daily operations of the business carried out the managers and employees.

On the other hand, the two-tier board system is commonly found in continental Europe (especially German) and Japan includes a Supervisory Board sitting between the shareholdersand the management board of directors. The German Supervisory Board, for instance, is made up of representatives from the employees as well as shareholders representatives in equal proportion in pursuance with the co-determination law. It also has the power to appoint and terminate services of the members of the management board. In terms of role, the supervisory board act as a monitoring or oversight (watch dog) while the management boards wield the decision making power.

This practices is argued to provide a real 'check and balance' of power for the management board to act in the best interest of the company's shareholders and other stakeholders. It also provides a double layer corporate governance to improve the company's management and board performance. It is interesting to note that corporate governance in the Islamic perspective is also having a two-tiered board. One is the management board and the other is the Shariah Supervisory Board (SSB). The SSB acts as an advisor to the management board on shari'ah (Islamic laws) matters to the management board, however; the final decision still relies on the management board (Ghayad, 2008).

In countries such as the United States and United Kingdom adopted the Anglo-American model which is also known as the 'shareholder model' (Franks and Meyer, 1994 cited in Ooghe and Langhe, 2004). The continental European and the Latin countries adopted the stakeholder's model which identifies with the German and Japan models. The differences in the model lie in the way in which ownership and control are organized or for contextual benchmark. 
In contrast, there is no consensus found in the literature on the concrete description of the Asian model (Luo, 2007 cited in Piesse et al., 2011). Some countries such as Japan, China,Korea and Thailand adopt the stakeholder's model while others like Singapore and Malaysia adopted the shareholder model. However the two features that are notable among the Asian countries are the predominance of family based shareholding and the complex networks of subsidiaries and related companies. It can be seen that the state or the government sometimes hold the majority shares in some big corporations in Asian countries. These corporations are known as the government-linked companies (GLCs). In most developing countries, the state also holds some interest in many companies of less strategic importance to the nation Khongmalai et al., 2007).

\subsection{Ownership and shareholders right}

Franks and Meyer (1994 as cited in Ooghe and Langhe, 2002) pointed out that the AngloAmerican countries have a low concentration of shareholders while in the continental European countries; they hold large proportion of publicly traded shares. While majority of company shares are held by agents of financial institutions (investment fund or trust fund) in the United States and United Kingdom, the majority shares in Germany, France and Italy are held by private companies (Prowse, 1994, Moerland, 1996, Gelauff and Broeder, 1997 cited byOoghe and Langhe, 2002). Degree of shareholding voting power concentration or block holding is very high in Europe than that in the United States or United Kingdom. This indicates the relationship between ownership and control. The larger the block holding, the more powerful is the control of the shareholders on the company.

Family and statecontrolled companies are common in the continental European countries with poor shareholder protection. Companies of this sort are characterised by having pyramidal or complex structures and mutual or reciprocal shareholders as a way to separate ownership from control (Ooghe and Langhe, 2002). The pyramidal ownership provides the means by which controlling shareholders have greater control rights over the cash flow ownership rights. As such, there can be easier access to the cash flow by the shareholders.

In the Anglo-American model, the decision-making authority lies with the management because of low concentration of shareholders. The power to make decision in the continental European model, by contrast, is in the hands of a single or few major shareholders. Therefore, the agency problems related to the Anglo American model arises between the many dispersed shareholders and management as opposed to the major shareholders against the minority shareholders of the continental European model.Beside Europe, family-based ownership concentration is also prominent in many Asian and developing countries (Piesse et al., 2011). In addition, Claessens et al., 2000 as cited by Piesse et al., 2011 noted that the state or the government is also an established shareholderin many Asian and Latin American countries (Khongmalai et al., 2010).

\subsection{Board of directors role}

The board is defined as the relationship between the shareholders and the management entrusted with the day to day responsibilities of the organization (Styles and Taylor as cited by Okpara, 2011). Tricker (2009) made a distinction between governance and management by examining the composition of the board. The board of directors as the governing body provides governance with a varying degrees depending upon the board structure comprised of the executive directors and the non-executive directors or the outside directors. Executive directors are employees of the company while non-executive directors are not the executives of the company nor have some relationship with the company. Non-executive directors can be further divided into independent non-executive directors (have no/indirect relationship with the company) and the connected non-executive directors (have a direct relationship with the company).

Basically, there are four functions of the board, (1) Accountability; (2) Supervision of the executives' activities; (3) Strategy formulation; and (4) Policy making, are the basic elements that directors must undertake. Accountability and supervision are essentially the roles concerned with conformance while strategy formulation and policy making are related to performance. In a two-tiered board, the roles are separated with the executive board responsible for performance and the supervisory board responsible for conformance and compliance.

Therefore, selection of directors is the most important factor in determining who exercised control within the board (Mace, 1971, Styles and Taylor, 2001 as cited by Piesse et al., 2011). Selections of the board members who are 
qualified and knowledgeable in their field and competent in decision making are a prerequisite for an effective board (Franksand Jensen, 1983, Kosnik, 1987 as cited by Piesseet al., 2011). In the case of state-owned enterprise, the state or the government will select the directors to represent their interest. Most of the board members appointed are senior civil servants (Khongmalai et al., 2010).

\subsection{Regulatoryframework and control mechanism}

Active market for takeover plays an important role in corporate governance in Anglo-American system as it imposes good discipline on the boards and management (Kimber and Lipton, 2005). Moreover, poor performing companies would be the subject to offer by better performing companies in a hostile takeover. So, it put pressure on the managementto manage the corporation assets better even if a take-over does not take place.

Financial structure is also an important source of discipline on managers particularly the choice of debt. If a company takes on debt, it would steadfastly limit how inefficient management can be, otherwise the company will suffer from the consequences as a result of bankruptcy proceeding. However this can only be effective if bankruptcy law and proceedings are well in place.

\subsection{Disclosure and transparency}

Credible disclosure and transparency is a symptom of good corporate governance and it is vital for allocation of scarce resources. With credible disclosure, existing and potential investors may be able to distinguish between good and bad corporate decisions at an average level (Healy and Papelu, 2000 as cite byOkpara 2011). Adverse selection avoidance, disclosure and transparency should therefore lower the firm's cost of capital as investors become sceptical (Lundholm and van winkle 2006 as cited by Okpara, 2011).

Sokol (2009) argued that the importance of laws and legal provisions to promote good corporate governance and transparency of state-owned postal services in Chile, New Zealand, the United Kingdom, Sweden, South Africa, Canada, Korea, Japan and the United States. Transparency is depending upon the governance mechanismbrought about by the enforcement of legal and regulatory requirements. Level of governance, on the other hand, was influenced by provisionfor profit maximisation and this was reflected by the board selection. Empirical study of state-owned hotel in china by Tang (2006) also suggested that among other critical issues, lack of transparency as a result of conflict of interest between ownership and management exacerbated the situation.

\subsection{Summary}

This study is intended to fill the gap in the literature of corporate governance model in state-owned enterprises from the context of an Asian emerging market. We believe that this study is among the first to examine corporate governance practices (model) in this market. It is important as the government is trying to attract more foreign direct investments (FDI) into the country. Not only it is useful for the academics but also to the companies which have a direct or indirect interest or plan to invest in this country.

\section{Research Methodology}

\subsection{Research design}

The case study focussed on the corporate governance model of a state-owned company, Company R. A qualitative approach was taken and interviews are conducted (Baxter and Jack, 2008). One of the interviewee is the corporate secretary who is also a senior government servant. A check list is developed to serve as the research instrument (Appendix 1).

\subsection{Sample selection}

The sample is selected using purposive sampling method or convenience sampling (Yaacob et al., 2012). This is due to the difficulties to get samples for this study. Having that, a single case study is applied. As this is a single case study, only one company is chosen as the sample (Yin, 1994) 


\subsection{Data collection}

Primary data are collected from interviews with two members of the organization. Names are withheld upon request by the interviewees. Secondary data are gathered from the company's publications and website, newspaper and publicly available information.

\subsection{Background of Company $R$}

Company R was established in the year 1974. It is one of the state-owned companies in the country, State B, formed even before the country's independence. Its headquarters is in the capital city of State B. It is a wholly-owned company by the state government. It has offices in more than 40 countries worldwide such as Australia, Spain, Switzerland, the UK, Japan and Netherland. The company currently employed over one thousandpersonnel.

The study categorized the growth of Company into three phases. The first phase is the beginning stage. The company expanded its operation in the South East Asean region. The second phase as the growing stage where further expansion into the Asean region and Australia. The country achieved its independence during this period. The final stage is the stabilizing stage where additional operations into the Middle East and Europe started. Currently, the company's operation covers the Asian, Australia, the Middle East and European region.

\section{Findings and Discussion}

This exploratory study investigates the corporate governance practices and issues relating to Company $\mathrm{R}$ as one of the countriesrelatively well established state-owned enterprise. The findings from our personal interview with the related government sector on the aspects covered under the literature review will shed light on the model of corporate governance of Company R. The dimensions include governance structure, ownership, and shareholders right, roles of the board, regulatory framework and control mechanism and disclosure and transparency.

\subsection{Governance structure}

The structure of corporate governance of Company $\mathrm{R}$ is typical of the unitary board system in the Anglo-American model whereby the board of director's claims accountability to the shareholders as the governing body entrusted with duties and responsibilities to manage the entire business operations and to oversee the management of the company.

Figure 1. The corporate governance model of Company $\mathrm{R}$ 


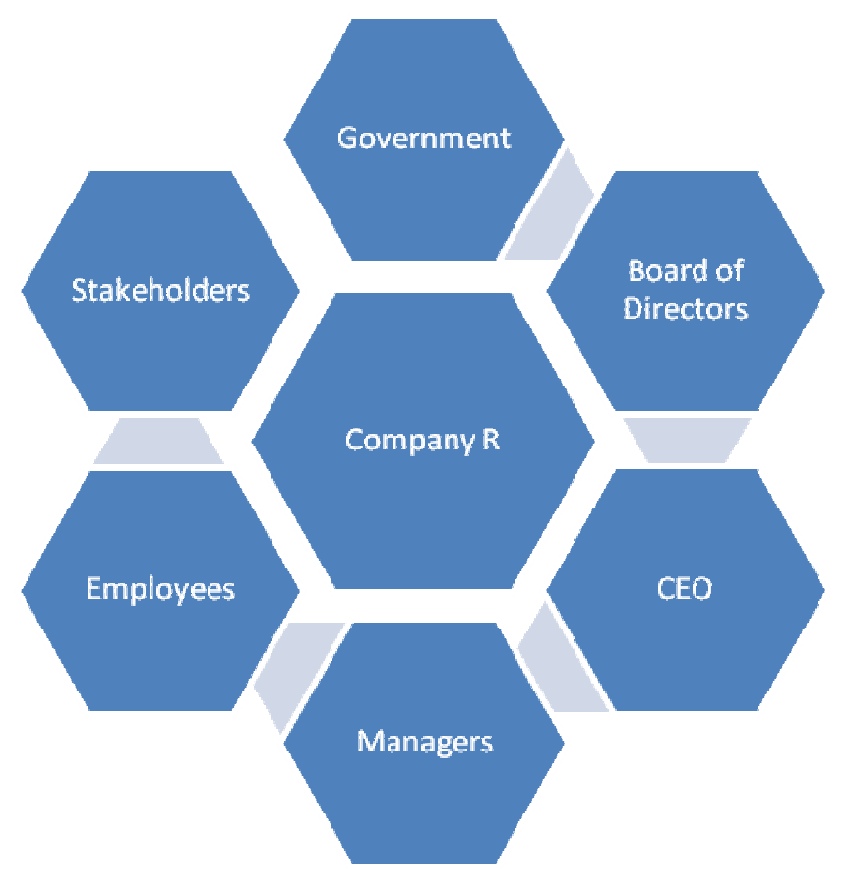

The shareholding of the company is $100 \%$ in the hands of the government. One senior minister represented the government as the main proxy. All the directors are non-executive members and all of them are senior government officials from various government departments. Except for one representative from the financial industry, however, that financial institution is also a government linked company (GLC). It is apparent that the board lacks independence but that does not seem to have any conflict of interests as they the individuals are of high level of competence and trustworthiness, who represented and safeguarded the state's interest.

The company has also never practiced CEO duality in that the CEO (previously Managing Director) bears greater sense of accountability to the board pertaining to the overall business operations and financial performance. He is assisted by several senior executives including a Chief Operating Officer(COO) and the Chief Financial Officer (CFO) in the day-to-day operations. Overall, the company employed over 1000 staff members including those who are under the company subsidiaries.

\subsection{Ownership and shareholderrights}

The structure of ownership of Company $\mathrm{R}$ is different from that of Anglo-American and the continental European and Japanese models. It is typical of some of the business organization in Asia whereby the state has full ownership and control over the company (Khongmalai et al., 2010). As the government is the only shareholder, the issue of unfair treatment of other minorityshareholders does not exist. Separation of ownership from control as advocated by scholars and practitioners alike for good governance is also not an issue that deserves attention because of only a single owner as the shareholder. However, agency problems between shareholder and management may arise and the board should be watchful of the managementbusiness conduct and performance particularly following recent unfavourable incidents (not elaborated).

\subsection{Roles of the board}

As far as the selection of the board members is concerned, the company has come of age with the direct involvement from the government in selecting a team of competent and knowledgeable individuals to sit on the board, the nonpaid member are withoutdoubt capable of carrying out their duties to ensure the board's functions in term of accountability, supervision of executivesactivities, strategy formulation and policy making can be fulfilled.

This is of course with the assistance of the CEO and the senior management executives. The management would in turn carry out their respective responsibilities with their subordinates. 


\subsection{Regulatory framework and control mechanism}

As the board of Company $\mathrm{R}$ is practically under direct vigilant control of the government (Ministry of Finance), the conduct of the business seems to be in increasingly satisfactory order. As can be seen from best practices, good corporate governance can be achieved not only through concerted efforts by the parties concerned but also from the legal and regulatory provisions that are complemented by sound internal controls.

Notwithstanding the ownership or the company, it is treated like any other company in that it is subject to filing of annual audit report to the authority in accordance with the Companies Act. Although it is well behind in its submission, the company had increased its efforts to get its act together so that the audited financial statements are up-to-date. Without special treatment, the company is liable to pay any applicable penalty and fine due to its noncompliance for the submission of the annual audit report.

The board being the governing body is answerable only to the government, being the sole shareholder. The regular board meetings would not include the presence of the shareholder however; the board is bound to present regular report on the overall performance including the financial performance of the company. Issues of primary concern of the shareholder would invariably be on how the company resources have been spent, the revenue generated, profit or loss made and control of expenditures. There has been a growing demand from the shareholder towards profit making performance in recent times. Any major decisions to be made shall require the consent by the shareholder this should be strictly adhered to.

As part of the internal controls, the company now pays more attention to details by having any transactions documented, thus providing paper trails in all of its dealings. Award of any projects must be by the way of open tender by at least a few bidding companies and proper evaluation done to assess the viability. The audit committee of the board would be responsible for the regular internal and external audit exercises and ensures compliance with rules and regulations in all matters, not only limited to financial affairs of the company.

\subsection{Disclosure and transparency}

Among the requirements under the Companies Act is the submission of annual report including an audit report to the government, which the company is subjected to? Even with the filing of its audited financial reports, it is a normal practice among state-owned companies not to publish them for public perusal. Financial performances of the government linked companies are kept under strict confidence, accessible only to certain authorised parties.

The government in its efforts to increase investor'sconfidence will set up an accounting standard council under the proposed Accounting Standards Order to conform to the International Accounting Standards (IASs) and International Financial Reporting Standards (IFRSs). These standards will be the benchmark for any limited liabilities companies in the country to perform. Until then, the company must double its efforts to shore up its level of preparedness for such scrutiny for the best national interest. However, the current securities order to some extent makes it mandatory for disclosure of certain documentation when making a transaction but may prove futile for many purposes in the absence of a stock exchange.

\section{Conclusions}

This study revealed that the corporate governance structure of Company Ris of the unitary or one-tier board system. It has similaritieswith the Anglo-American model. However, most American companies are owned by a wide variety of shareholders, Company $\mathrm{R}$ is state-owned, where thegovernment is the sole shareholder. All the directors are nonexecutive members who are highly competent and trustworthy senior government officials. They are supposed to uphold the governmentinterest. In terms of Chief Executive Officer'duality' role, it has never been practiced.

The board of directors are selected through stringent selection process by the government department in charged. The members should be able to and highly capable in terms of accountability, supervising executives' activities, formulating strategies, and making policies. The CEO and the senior management team would then assist the board 
of directors through their respective responsibilities. Appointment of expatriates who are highly qualified and experienced is deemed necessary to improve organizational and financial performance.

In accordance with CompaniesAct, albeit state-owned, the company is not exempted from audit report submission. Reports from board meetings containing vital informationon the overall performance of the company is regularly presented to the shareholder. Thus, any final decisions require consent from the shareholder.

Internal control measures like transactions documentation, audit exercises, evaluation processes prior to tender awards are given due attention. Like any other state-owned companies, the financial statements are not made public. In order to increase investor'sconfidence, the government is setting up an accounting standard council under the current AccountingStandards Order.

Furthermore, the issues in the agency theory are not applicable in this context. Although the director are appointed by the government (as the shareholder), they are more of stewards of the company because they have an apparent obligation (civil servants) to serve the nation and not having some personal interest in the company (Karns, 2011). Thus, the nation-state greatly influenced the governance of the economic entity (Company R) in which they are the sole shareholder.Finally, we found that Company R corporate governance model is highly influenced by the nationstate as the sole shareholders, therefore, making them as the sole authority (Lubatkin et al., 2005).

\section{References}

Baxter, P. and Jack, S. (2008), "Qualitative case study methodology: study design and implementation for novice researchers",The Qualitative Report, Vol. 13, No. 4, pp. 544 - 559.

Dalton, D.R. and Dalton, C.M. (2010), "Integration of micro and macro studies in governance research: CEO duality, board composition and financial performance”,Journal of Management, Vol.37, No.2, pp.404 - 411.

Davis, J.H., Schoorman, F.D. and Donaldson, L. (1997), "Toward a stewardship theory of management”,Academy of Management Review, Vol.22, No.1, pp.20 - 47.

Ghayad, R. (2008),“Corporate governance and the global performance of Islamic banks”,Humanomics, Vol.24, No.3, pp.207-216.

Karns, G.L. (2011),“Stewardship: a new vision for the purpose of business”,Corporate Governance, Vol.11, No.4, pp.337 - 347 .

Kimber, D. and Lipton, P (2005), “Corporate governance and Business ethics in the Asia Pacific region”,Business\& Society, Vol. 44, No.2, pp.178 - 210.

Khongmalai, O., Tang, J.C.S. and Siengthai, S. (2010), "Empirical evidence of corporate governance in Thai stateowned enterprises",Corporate Governance, Vol.10, No.5, pp.617 - 634.

Lubatkin, M.H., Lane, P.J., Collin, S.O. and Very, P. (2005), "Origins of corporate governance in the USA, Sweden and France",Organization Studies, Vol.26, No.6, pp.867 - 888.

Myers, P.M. and Ziegenfuss, D.E. (2006),“Audit committee pre-Enron efforts to increase the effectiveness of corporate governance",Corporate Governance, Vol.6, No.1, pp.49- 63.

OECD (2004),"Principles of corporate governance", Organization for Economic Cooperation and Development.

Okpara, J.O. (2011),"Corporate governance in a developing economy: barriers, issues and implication for firms",Corporate Governance, Vol.11, No.2, pp.184 - 199.

Ooghe, H. and Langhe, T.D. (2002),"The Anglo American versus the continental European corporate governance model: empirical evidence of board composition in Belgium",European Business Review, Vol.14, No.6, pp.437 - 449 .

Piesse, J., Strange, R. and Toonsi, F. (2011),“Is there a distinctive MENA model of corporate governance?”Journal of Management Governance, 8 July 2011, pp.1 - 37,

Smolo, E. and Smajic, M. (2011), "Recent fiasco in Qatar: The need for good governance”,ISRA Bulletin, 8, April 2011 , pp. $3-4$.

Sokol,D.D. (2009),“Competition policy and comparative corporate governance of state-owned enterprises",Brigham Young University Law Review,pp.1713 - 1812.

Strebel, P. (2011), "In touch boards: reaching out to the value critical stakeholders",Corporate Governance, Vol.11, No.5, pp.603 -610. 
Strikwerda, J. (2003), “An entrepreneurial model of corporate governance: devolving powers to subsidiary boards”, Corporate Governance, Vol.3, No.2, pp.38 - 57.

Tang, F.F., Xi, Y., Chen, G. andWang, R. (2006), “Ownership, corporate governance and management in the estateowned hotels in the People's Republic of China",Cornell Hotel and Restaurant Administration Quarterly, Vol.47, No.2, pp.182 - 191.

Tricker, B. (2009), “Corporate governance: principles, policies and practices”, New York: Oxford University Press.

Witt, A.M. (2012), “Editorial”,Asian Business \& Management, Vol.11, No.1, pp.1 - 4.

Yaacob, H.,Jaya, B.S. and Hamzah, M. (2012), "Stakeholders role in corporate governance: Evidence from Brunei's oil and gas industry",Proceedings of the 10th ASEAN Inter-University Seminars on Social Development Organized by Universiti Brunei Darussalam and National University of Singapore, Bandar Seri Begawan, Brunei.

Yin, R.K. (1994),“Case study research: design and methods”, Second Edition, Applied Social Research Methods, Series 5, Sage Publications.

Young, S. and Thyil, V. (2008), “A holistic model of corporate governance: a new research framework”,Corporate Governance, Vol.8, No.1, pp.94-108.

Appendix 1: Research instrument

The components are as follows:

1. The corporate structure of Company R.

2. Governance structure: the composition of the board, executive/non-executive directors, duality role of Chief Executive Officer and Chairman of the Board.

3. The roles of shareholders Board of Directors, Chief Executive Officer and managers.

4. Corporate governance practices.

5. Board committees and their functions (e.g. Audit, Compensation, Nomination, etc.).

Practices/implementations to promote both performance and conformance.

In terms of performance, any appointment of expatriate industry expert as CEO?

What actions are taken to improve performance?

In term of conformance, having independent directors?

What actions are taken to improve conformance?

6. The difference between previous and current board structure.

7. The significance of having expatriate industry Expert as CEO as opposed to previous experience.

8. Other practices / tools/ implementations which are part of corporate governance process e.g. risk management, internal controls etc.

9. Company R stance and commitment to corporate social responsibility. 